Arq. Bras. Med. Vet. Zootec., v.68, n.4, p.931-937, 2016

\title{
Electromyographic analysis of the gait cycle phases of boxer dogs
}

\author{
[Análise eletromiográfica do ciclo de marcha em cães da raça boxer] \\ J.F. Araújo ${ }^{1}$, F.B. Rodrigues ${ }^{2}$, F.G. Abadia $^{2}$, F.M. Gervásio ${ }^{1}$, G.B.N. Mendonça ${ }^{2}$, \\ A.D. Damasceno ${ }^{2}$, M.F. Vieira ${ }^{2}$ \\ ${ }^{1}$ Universidade Estadual de Goiás - UEG - Mineiros, GO \\ ${ }^{2}$ Universidade Federal de Goiás - UFG - Goiânia, GO
}

\begin{abstract}
Systematic studies involving technologies such as surface electromyography (sEMG) may provide important data that enable veterinarians to recognize musculoskeletal, ligamentous, and neurological alterations. The aim of this study was to describe the gait cycle phases and the timing of muscle activation in healthy Boxer dogs during gait by means of sEMG. The gait cycle of seven Boxer dogs was evaluated and sEMG was recorded from the biceps brachii, triceps brachii, brachiocephalic, rectus femoris, semitendinosus, semimembranosus, and superficial gluteal muscles of the right hemibody. Circular monopolar $\mathrm{Ag} / \mathrm{AgCl}$ electrodes were attached to the mean point between the motor point and the muscle insertion. The electromyographic signals were collected by an active interface with 20 -fold gain in a bipolar differential configuration using a 16-channel signal conditioner (EMG Systems Brasil), while the dogs walked on a treadmill at a speed of $2 \mathrm{~m} / \mathrm{s}$. Pearson's correlation was used for the statistical analysis. A positive correlation was found between the rectus femoris and biceps brachii $(\mathrm{r}=0.81)$; superficial gluteal and triceps brachii $(\mathrm{r}=0.69)$; semitendinosus-semimembranosus and biceps brachii $(\mathrm{r}=0.76)$; and rectus femoris and semitendinosus and semimembranosus muscle groups $(\mathrm{r}=0.99)$. The biceps brachii and brachiocephalic muscles work in tandem to position the thoracic limb during the gait cycle, while the semitendinosus-semimembranosus group flexes the knee and, simultaneously with the quadriceps that flexes the hip, prevents the contact of the pelvic limb with the ground during the swing phase. The body is propelled forward by the triceps brachii muscle, which extends the elbow and flexes the shoulder at the final contact, while the superficial gluteal muscle extends the hip.
\end{abstract}

Keywords: limb muscles, canine gait cycle, surface electromyography

\section{RESUMO}

Estudos sistemáticos que envolvem uso de tecnologias, como a eletromiografia de superfície (EMGs), podem fornecer dados importantes que capacitam os clínicos a diferenciar as alterações musculoesqueléticas, ligamentares ou neurológicas. Objetiva-se com este trabalho descrever as fases da marcha canina e o momento de ativação dos músculos de cães saudáveis da raça Boxer durante a marcha, por meio da eletromiografia de superfície. Avaliou-se a marcha de sete cães da raça Boxer, e o sinal elétrico da eletromiografia de superfície foi coletado do bíceps braquial, do tríceps braquial, do braquiocefálico, do reto femoral, do semitendinoso/semimembranoso e do glúteo superficial do hemicorpo direito. Os eletrodos monopolares circulares de prata com cloreto de prata $(\mathrm{Ag} / \mathrm{AgCl})$ foram posicionados no ponto médio entre a placa motora e a inserção desses músculos. Os sinais eletromiográficos foram capturados e adquiridos por uma interface ativa com ganho de $20 \mathrm{x}$ em configuração diferencial bipolar e por um condicionador de sinais (EMG Systems Brasil) de 16 canais, enquanto os cães caminharam em esteira com velocidade de $2 \mathrm{~m} / \mathrm{s}$. Para análise estatística, foi aplicado teste de correlação de Pearson. Verificou-se correlação positiva entre os músculos retofemoral e bíceps braquial $(r=0,81)$; glúteo superficial e tríceps braquial $(r=0,69)$; semitendinoso/semimembranoso $e$ bíceps braquial ( $r=0,76)$; e entre o músculo reto femoral e o grupo muscular semitendinoso $e$

Recebido em 25 de setembro de 2015

Aceito em 8 de janeiro de 2016

E-mail: jakelineferreiradearaujo@gmail.com 


\section{Araújo et al.}

semimembranoso $(r=0,99)$. Os músculos bíceps braquial e braquiocefálico do mesmo membro trabalham em sinergia para posicionar o membro torácico durante o ciclo de marcha, enquanto o grupo muscular semitendinoso/semimembranoso flexiona o joelho e, simultaneamente com o quadríceps, que flexiona o quadril, impede que o membro pélvico entre em contato com o solo no balanço. Para impulsionar o corpo à frente, o músculo tríceps braquial estende o cotovelo e flexiona o ombro no contato final e o glúteo superficial estende o quadril.

Palavras-chave: músculos, ciclo de marcha, eletromiografia de superfície

\section{INTRODUCTION}

Muscles in animals and humans provide the driving force for locomotion (Gamble and Rose, 2007). The gait, which propels the body from one point to another, requires the harmonious functioning of each system of the body, particularly the muscles and the osteoarticular apparatus.

The gait cycle of animals can be divided into two periods: stance and swing phases. Stance phase, which corresponds to the period in which the limb is in contact with the ground, comprises about $60 \%$ of the gait cycle and is divided into the following subphases: initial stance, response to load, intermediate stance, and final stance. Pre-swing is an intermediate phase between stance and swing phases. Swing phase, on the other hand, corresponds to the period in which the limb is not in contact with the ground. It comprises about $40 \%$ of the gait cycle and is also divided into subphases: initial, intermediate, and final swing, as described by Perry (2005). According to Badoux (1986) and Araújo (2005), propulsion is the instant when the animal is propelled forward, corresponding to the intermediate phase between stance and swing.

Weigel et al. (2008) defined the length of the stride as the distance between the first and second contact points with the ground of the ipsilateral limb and the gait cycle as the time it takes for each of the four limbs to complete the stride. Dogs may present a lateral and/or diagonal gait. The lateral gait occurs when the ipsilateral thoracic limb (TL) and the pelvic limb (PL) perform the step, i.e., when they are simultaneously in stance or swing. In diagonal gait, on the other hand, the TL of one side meets the contralateral $\mathrm{TL}$ at the same time (Gillette, 2004).

The morphology and mechanism of muscle contraction in dogs is similar to that of humans, which enables their movement to be studied using the same tools (Guyton and Hall, 2002). Surface electromyography (EMG) is a diagnostic tool that is easy to use and inexpensive. Although EMG has been used in veterinary medicine since the $1960 \mathrm{~s}$, its use in veterinary clinical practice in Brazil only began in 1988 (Souza et al., 2006).

Systematic studies involving technologies such as surface electromyography (EMG) can provide veterinarians with important data that enable them to differentiate muscle, ligament, skeleton or neurological alterations that affect locomotion (Weigel et al., 2008). EMG has been employed in numerous studies to determine muscle function in equine athletes and in felines with secondary nutritional hyperparathyroidism (Colborne et al., 2001; Peham et al., 2001; Rahal et al., 2003; Wijnberg et al., 2003; Licka et al., 2004; Wijnberg et al., 2004).

Therefore, the purpose of this work is to describe the phases of canine gait and the muscle activation of healthy Boxer dogs during the gait cycle by means of surface electromyography, proving information to improve veterinary diagnostic methods and the quality of treatments of orthopedic and neurological diseases in this canine breed.

\section{MATERIAL AND METHODS}

This study was approved by the Ethics Committee for Human and Animal Research of the Universidade Federal de Goiás - UFG, under Protocol $\mathrm{N}^{\circ}$ 006/2010, and was performed according to the ethical guidelines for animal experimentation. This cross-sectional experimental study was conducted at the Bioengineering and Biomechanics Laboratory of UFG.

The experiment, for which samples were chosen by convenience, involved seven clinically 
healthy adult (2 to 8 years) Boxer dogs of both sexes, with similar morphological characteristics: a wither height between 57 to $63 \mathrm{~cm}$, and body weight varying from 28 to $35 \mathrm{~kg}$. A pilot study was conducted for corrected positioning and placement of the electrodes, definition of limbs and muscles to be evaluated, electromyographic signal collection procedure, data processing, and analysis. All experimental steps were performed on the same day.

To teach the dogs to walk on the treadmill (ProAction, BH Fitness ${ }^{\circledR}$, Spain) at a speed of $2 \mathrm{~m} / \mathrm{s}$, they were restrained with a leash or restrained manually by the owner, along with the research participants (Figure 1).

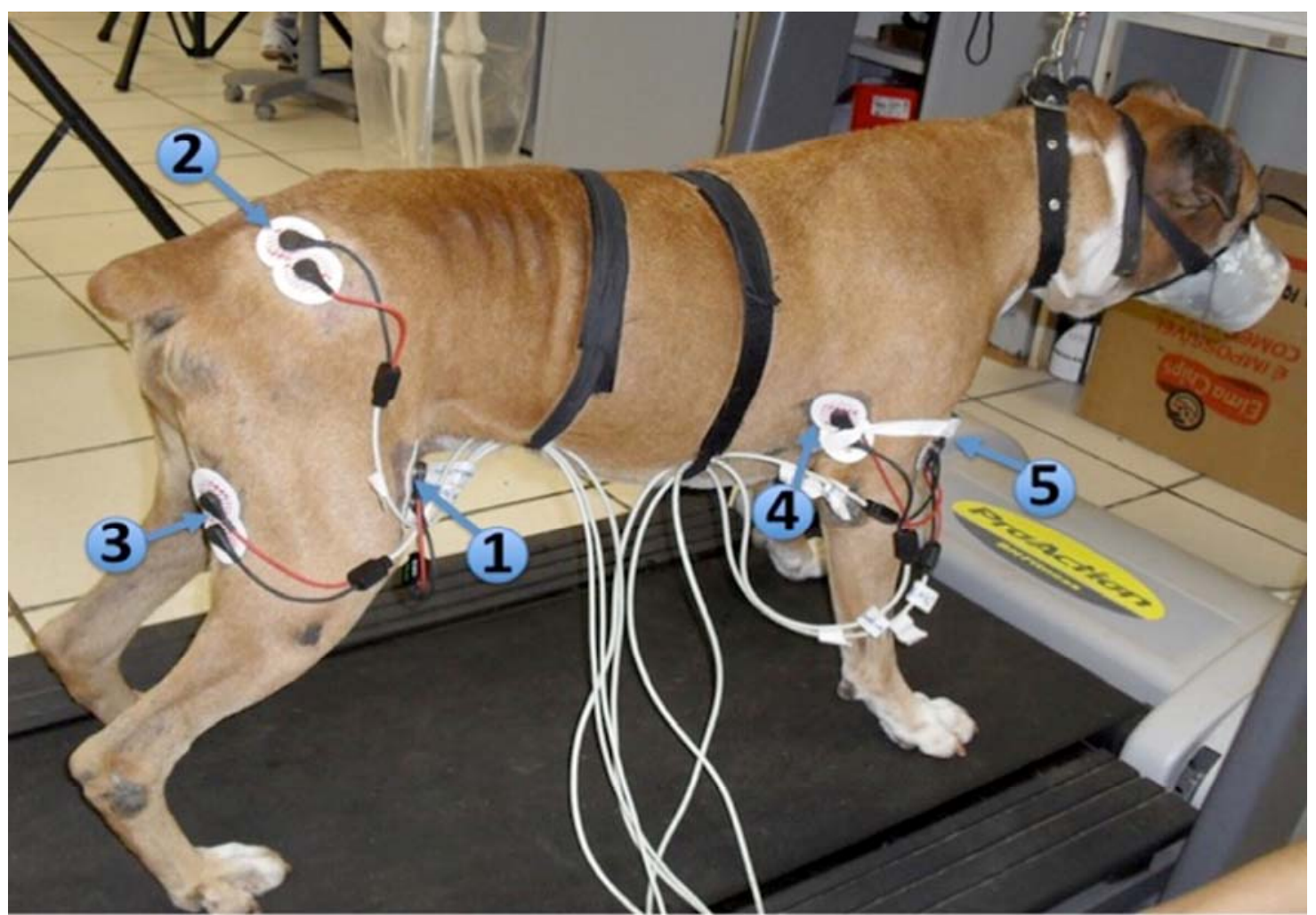

Figure 1. Boxer dog restrained with a leash, positioned on the treadmill and connected to the wires of the surface electromyography apparatus by electrodes attached to the shaved skin lateral to the rectus femoris (1), superficial gluteal (2) and semitendinosus-semimembranosus muscles (3) of the pelvic limb (PL), and triceps brachii (4), biceps brachii (5) and brachiocephalic muscles (not shown) of the thoracic limb (TL).

The electrodes were positioned and attached to the skin, which was first shaved and cleaned with neutral detergent and alcohol. Self-adhesive disposable $8 \mathrm{mmAg} / \mathrm{AgCl}$ circular monopolar electrodes with conductive gel were attached to the skin at a distance of $20 \mathrm{~mm}$ from each other, as recommended by the SENIAM project (Surface ElectroMyoGraphy for the NonInvasive Assessment of Muscles). The electrodes were placed at the intermediate point between the motor point and the muscle insertion to record the activation of the motor units.
The electromyographic evaluation was conducted on the thoracic limb and the ipsilateral pelvic limb of each animal. The right body size was randomly chosen in the pilot study. The flexor and extensor muscles around the shoulder girdle, and knee and hip joints, were evaluated during all phases of the gait cycle: brachiocephalic muscle, triceps brachii muscle, biceps brachii muscle, superior gluteal muscle, semitendinosus and semimembranosus muscle group, and the rectus femoris muscle.

The data was collected with the animal walking on the treadmill (ProAction, BH Fitness ${ }^{\circledR}$, Spain) 
at a constant speed of $2 \mathrm{~m} / \mathrm{s}$ in three successive series of 20 seconds each. Each data series collection starts at the moment the palmar pad of the right thoracic limb of the dog touched the treadmill.

The data were collected by an active interface with 20-fold gain in bipolar differential configuration and a 16-channel signal conditioner (EMG Systems do Brasil, São José dos Campos, SP), with 100-fold amplification (2000-fold total amplification), common rejection mode of $90 \mathrm{~dB}$, analog bandpass filter with a cutoff frequency of 20 to $500 \mathrm{~Hz}$ and analog-to-digital converter with 16 bits resolution.

The signals were acquired at a sampling frequency of $2.0 \mathrm{kHz}$ and processed in the time domain by calculation of root mean square (RMS) value with a $500 \mathrm{~ms}$ window. A correlation analysis was conducted, with a significant level set at $\mathrm{P}<0.05$. During the data acquisition, the animal was also filmed as it walked on the treadmill, using a Sony, Cybershot DSC-HX7V camera operating at $60 \mathrm{~Hz}$, in order to record the anatomical position of the TL and the PL in each phase of the gait cycle. The films were further analyzed frame by frame.

\section{RESULTS AND DISCUSSION}

Surface EMG was chosen because it is painless, non-invasive and provides a functional evaluation of the animal's gait. Basmajian and De Luca (1985), Cram and Kasman (1998), and Merletti (2004) stated that EMG is an important and reliable resource to evaluate muscle contractions in humans. In addition, the use of sEMG on animal research is innovative, since there are only a few studies in literature.

The study involved five female and two male Boxer dogs with an average age of $57.57 \pm 18.36$ months, weight of $32.04 \pm 3.86 \mathrm{~kg}$ and wither height of $55.71 \pm 1.11 \mathrm{~cm}$. It was observed that the dogs presented lateral gait, which, according to Gillette (2004), is the normal dog gait. Analyzing the videos, we characterized the gait cycle in (1) stance phase with the subphases: initial contact (palmar pad touching the ground), load response (weight discharge), intermediate stance (limb perpendicular to the ground), final stance (extended limb), pre-swing (digital pad leaving the ground) (Figure 2); and (2) swing phase with the subphases: initial swing (limb at the beginning of oscillation), intermediate swing (PL reaches the ipsilateral TL), final swing (limb prepares to touch the ground) (Figure 3).

The EMG signals were analyzed at each phase of the gait cycle (Table 1 and 2). Eccentric action represents the activation of a muscle in response to the primary action of its antagonist, identified in the EMG signal.

The results in Tab. 1 and 2 were presented as suggested by Silva (2006), who performed a kinematic analysis of the gait cycle of Golden Retriever dogs, considering the scapulohumeral, cubital, carpal, coxofemoral, femorotibial, and tarsal joints during two seconds. In this study, we observed that the decrease of the joint angle flexion - occurred in the swing phase, while the increase of the joint angle - extension - occurred in the stance phase.

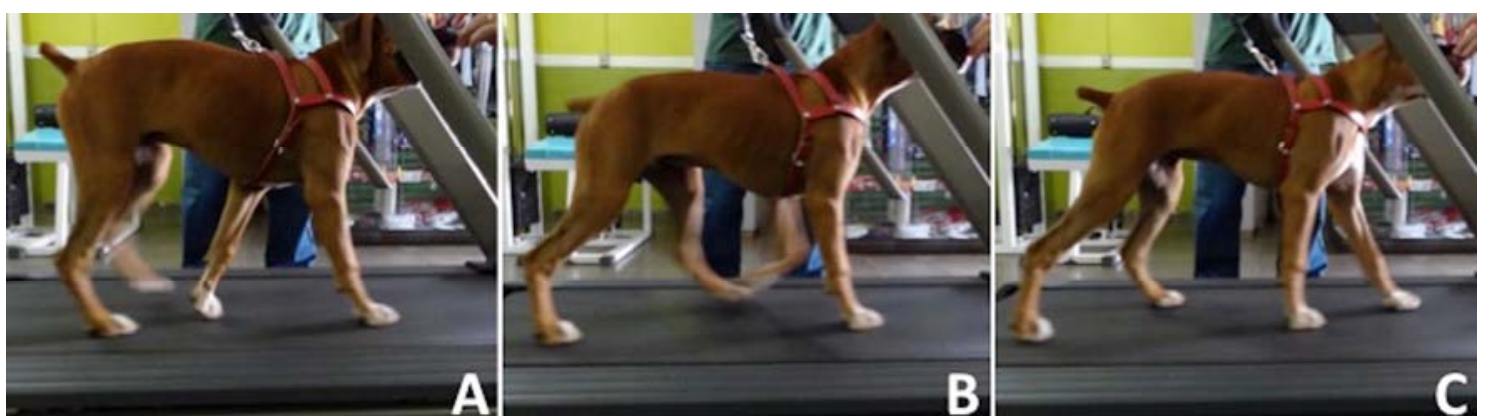

Figure 2. Stance phase and subphases. (A) initial stance: Right TL and PL touch the treadmill. (B) intermediate stance: right TL and PL are perpendicular to the ground. (C) final stance: the shoulder is flexed, elbow is extended and right PL is extended. 

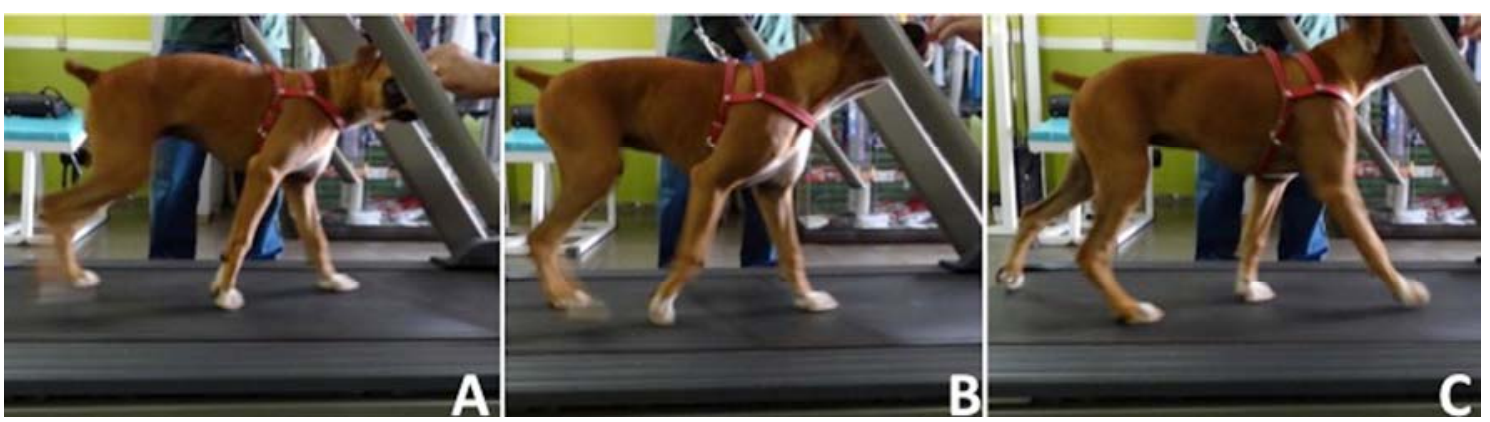

Figure 3. Swing phase and subphases. (A) initial swing: beginning of the flexion of TL and PL joints to lift the limbs from the ground. (B) intermediate swing: all the TL and PL joints are flexed. (C) final swing: TL and PL touch the treadmill.

Table 1. Action of biceps brachii, triceps brachii, brachiocephalic, rectus femoris, semitendinosus/semimembranosus and superficial gluteal muscles activated in the stance subphases in Boxer dogs

\begin{tabular}{lllll}
\hline Phase & Stance & & & \\
Subphases & & Load response & Intermediate stance & (C) Final stance \\
Muscles & Initial contact & & & \\
\hline Biceps brachii & Shoulder: extension & Shoulder: eccentric action & Shoulder: eccentric action & Shoulder: eccentric action \\
& Elbow: eccentric action & Elbow flexion & Elbow: flexion & Elbow: eccentric action \\
Triceps brachii & Shoulder: eccentric action & Shoulder: flexion & Shoulder: flexion & Shoulder: flexion \\
Brachiocephalic & Elbow: extension & Elbow: eccentric action & Elbow: eccentric action & Elbow: extension \\
Rectus femoris & Shoulder: extension & Shoulder: eccentric action & Shoulder: eccentric action & Shoulder: eccentric action \\
Semitendinosus- & Knee: extension & Hip: flexion & Hip: flexion & Hip: eccentric action \\
Semimembranosus & Knee: eccentric action & Knee: eccentric action & Knee: eccentric action & Knee: extension \\
Superficial gluteus & Hip: flexion & Hip: eccentric action & Hip: eccentric action & Hip: extension \\
& & Knee: flexion & Knee: flexion & Knee: eccentric action \\
\hline
\end{tabular}

Table 2. Action of biceps brachii, triceps brachii, brachiocephalic, rectus femoris, semitendinosussemimembranosus and superficial gluteal muscles activated in the swing subphases in Boxer dogs

\begin{tabular}{lllll}
\hline Phase & Swing & & & \\
\hline Subphases & Pre-swing & Initial swing & Intermediate swing & Final swing \\
Muscles & & & & \\
\hline Biceps brachii & Shoulder: eccentric action & Shoulder: eccentric action & Shoulder: extension & Shoulder: extension \\
& Elbow: eccentric action & Elbow: flexion & Elbow: flexion & Elbow: eccentric action \\
Triceps brachii & Shoulder: flexion & Shoulder: flexion & Shoulder: eccentric action & Shoulder: eccentric action \\
Brachiocephalic & Elbow: extension & Elbow: eccentric action & Elbow: eccentric action & Elbow: extension \\
& Shoulder: eccentric action & Shoulder: eccentric action & Shoulder: extension & Shoulder: extension \\
Rectus femoris & Hip: eccentric action & Hip: flexion & Hip: flexion & Hip: flexion \\
Semitendinosus/Semim & Knee: extension & Knee: flexion & Knee: flexion & Knee: extension \\
embranosus & Hip: extension & Hip: eccentric action & Hip: eccentric action & Hip: eccentric action \\
Superficial gluteus & Knee: eccentric action & Knee: eccentric action & Knee: eccentric action & Knee: eccentric action \\
& Hip: extension & Hip: eccentric action & Hip: eccentric action & Hip: eccentric action \\
\hline
\end{tabular}

A correlation analysis of the TL and PL muscles revealed that most of the muscles were weakly correlated (Tab. 3). However, a strong correlation was found between the rectus femoris and biceps brachii muscles $(\mathrm{r}=0.81, \mathrm{p}=\mathrm{xxx})$, as well as between the superficial gluteus and triceps brachii muscles $(r=-0.69, \mathrm{p}=\mathrm{xxx})$. While some of TL and PL muscles, mainly, the recitus femoris and biceps brachii perform their primary action, other muscles are eccentrically active to stabilize the joints involved in the initial contact and final stance subphases (Tab. 1).

Strong correlation was also found between the semitendinosus-semimembranosus group and the biceps brachii $(r=0.76, p=x x x)$, since they have to perform the knee and elbow flexion, respectively, during the swing phase, to ensure the limb will not drag. 
Table 3. Correlation matrix of the muscles of the thoracic limbs (TL) and pelvic limbs (PL) of Boxer dogs. The top diagonal shows the Pearson correlation and the bottom diagonal shows the $\mathrm{p}$ values $(\mathrm{P}<$ $0.05)$

\begin{tabular}{|c|c|c|c|c|c|c|}
\hline Muscles & $\begin{array}{l}\text { Muscles } \\
\text { Biceps } \\
\text { brachii }\end{array}$ & $\begin{array}{l}\text { Triceps } \\
\text { brachii }\end{array}$ & Brachiocephalic & $\begin{array}{l}\text { Rectus } \\
\text { femoris }\end{array}$ & $\begin{array}{l}\text { Semitendinosus / } \\
\text { Semimembranosus }\end{array}$ & $\begin{array}{l}\text { Superficial } \\
\text { gluteus }\end{array}$ \\
\hline Biceps brachii & & 0.41 & 0.34 & $0.81 *$ & $0.76^{*}$ & -0.40 \\
\hline Triceps brachii & 0.354 & & -0.51 & 0.33 & 0.37 & -0.69 \\
\hline Brachiocephalic & 0.442 & 0.243 & & 0.01 & -0.02 & 0.35 \\
\hline Rectus femoris & 0.029 & 0.465 & 0.991 & & $0.99 * *$ & -0.38 \\
\hline $\begin{array}{l}\text { Semitendinosus- } \\
\text { Semimembranosus }\end{array}$ & 0.045 & 0.415 & 0.971 & 0.000 & & -0.41 \\
\hline Superficial gluteus & 0.376 & 0.084 & 0.440 & 0.397 & 0.358 & \\
\hline
\end{tabular}

Biceps brachii and brachiocephalic muscles act sequentially in shoulder extension during the initial contact and eccentrically in all the stance and swing phases. However, they presented a weak correlation, suggesting co-contraction. The function of the brachiocephalic muscle is to extend the shoulder, working as an auxiliary muscle to the biceps brachii. This ensures that, in cases of neurological or muscle lesions, one of these muscles will act to maintain the animal's partial gait capacity (Dyce et al., 2004). This also explains the weak correlation between biceps brachii and triceps brachii, which are antagonists during shoulder and elbow flexion/extension.

The triceps brachii and brachiocephalic muscles did not present a significant correlation, possibly because the main function of the brachiocephalic muscle is to control the head during static and dynamic postures. The triceps brachii muscle participates actively in almost the entire cycle, since it has to keep the elbow slightly extended during all the stance subphases. Simultaneously, it acts to flex the shoulder and extend the elbow in the final stance to propel the body. Upon initial contact, it extends the elbow to position the thoracic limb.

In this study, we analyzed the extrinsic shoulder muscles that play an important role in the gait cycle. On the other hand, Carrier et al. (2008) used invasive electromyography to analyze the action of the intrinsic shoulder muscles of dogs and found that little or even no force is applied on this articulation in the stance phase of the gait cycle.

With regard to the PL muscles, the correlation between the rectus femoris muscle and the semitendinosus-semimembranosus muscle group was positive $(r=0.99)$, as expected, since the electrodes captured the signals of two muscles simultaneously. In addition, it should be considered the possibility of increased crosstalk, which is a problem inherent to the EMG of intimately connected small muscles, according to Licka et al. (2009). This muscle group presented a negative correlation with the superficial gluteal muscle, albeit without statistical significance, possibly because they act in different joints or present alternate instants of concentric and eccentric contractions in relation to each other.

The rectus femoris muscle was also found to be negatively correlated with the superficial gluteal muscle, without statistical significance, which is explained by the eccentric and concentric activity of the rectus femoris muscles in hip flexion and in knee stabilization during the gait cycle. A remarkable characteristic of the dog's gait, also described by Getty (1986), is the constant knee and hip flexion during almost the entire gait cycle, which was confirmed by the electromyogram of the rectus femoris and semitendinosus and semimembranosus muscles, whose amplitude increased in the critical instants of response to load and swing. This demonstrates the importance of those muscles in these joints, since any alteration can make the animal drag its pelvic limbs.

\section{CONCLUSIONS}

Pelvic and thoracic limb muscles act harmoniously to propel the animal's body forward. The biceps brachii and brachiocephalic muscles in the same limb work sequentially to position the thoracic limb during the gait cycle, while the semitendinosus-semimembranosus muscle group flexes the knee and, simultaneously with the quadriceps muscle that flexes the hip, prevents the pelvic limb from 
touching the ground during the swing stance. To propel the body forward, the triceps brachii muscle extends the elbow and flexes the shoulder at the final contact while the superficial gluteus extends the hip.

The findings of this study are useful as a reference to determine the nature of claudication or paresis and to monitor the recovery of Boxer dogs subjected to clinical, surgical or physical therapies.

\section{REFERENCES}

ARAÚJO, A.G.N.; ANDRADE, L.M.; BARROS, R.M.L. Sistema para Análise Cinemática da Marcha Humana Baseado em Videogrametria. Rev. Fisiot. USP., v.11. p.3-10. 2005.

BADOUX, D.M. Biomecânica In: GETTY, R. Anatomia dos animais domésticos. 5.ed. Rio de Janeiro: Guanabara-Koogan. 1986. Cap. 5. p.47-79.

BASMAJIAN, J.V.; DE LUCA, C.J. Muscles alive: their functions revealed by electromyography. 5.ed. Baltimore: Williams \& Wilkins, 1985. 561p.

CARRIER. D.R.; DEBAN, S.M.; FISCHBEIN, T. Locomotor function of forelimb protractor and retractor muscles of dogs: evidence of strut-like behavior at the shoulder J. Exp. Biol., v.211. p.150162. 2008.

COLBORNE, G.R.; BIRTLES, D.M.; CACCHIONE, I.C. Electromyographic and kinematic indicators of fatigue in horses: a pilot study. Equine Vet. J. Suppl., n.33, p.89-93. 2001.

CRAM, J.R.; KASMAN, G.S. Introduction to surface electromyography. Gaithersburg: Aspen Publication, 1998. 408p.

DYCE, K.M.; SACK, W.O.; WENSING, C.J.G. Tratado de anatomia veterinária. 3.ed. Rio de Janeiro: Elsevier, 2004. 663p.

GAMBLE, J.G.; ROSE, J. Marcha: teoria e prática da locomoção humana. 3.ed Rio de Janeiro: Guanabara Koogan, 2007. 257p.

GETTY, R. Sindesmologia. In: GETTY, R. Sisson/Grossman anatomia dos animais domésticos. 5.ed. Rio de Janeiro: Guanabara Koogan, 1986. p.3337.

GILLETTE, R. Gait analysis. In: MILLIS, D.L.; LEVINE, D.; TAYLOR, R.A. Canine reabilitation $e$ physical therapy. Philadelphia: Saunders, 2004. p.201210.
GUYTON. A.C.; HALL. J.E. Tratado de fisiologia médica. 10.ed. São Paulo: Guanabara Koogan, 2002. 632p.

LICKA, T. F.; PEHAM, C.; FREY, A. Electromyographic activity of the longissimus dorsi muscles in horses during trotting on a treadmill. Vet. J., v.180. p.71-76, 2009.

LICKA, T.F.; PEHAM, C.; FREY. A. Electromyographic activity of the longissimus dorsi muscles in horses during trotting on a treadmill. Am. J. Vet. Res., v.65, p.155-158, 2004.

MERLETTI, R. Electromyography: physiology, engineering and non-invasive applications. New Jersey: John Wiley \& Sons, 2004. 520p.

PEHAM, A.; FREY, T.; SCHIDL, M. Evaluation of the EMG activity of the long back muscle during induced back movements at stance. Equine Vet. J. Suppl., n.5, p.165-168, 2001.

PERRY, J. Análise de marcha.. São Paulo: Manole, 2005. 191p.

RAHAL, S.C.; RESENDE, L.A.L.; MORTARI, A.C. et al. Avaliação eletroneuromiográfica em gatos normais e submetidos ao hiperparatiroidismo secundário nutricional. Braz. J. Vet. Res. Anim. Sci., v.40, supl. 1, p.39-45, 2003.

SILVA, G.C.A. Análise cinemática da marcha de cães da raça Golden Retriever saudáveis. 2006. 84f. Dissertação (Mestrado em Ciências) - Faculdade de Medicina Veterinária e Zootecnia, Universidade de São Paulo, São Paulo, SP.

SOUZA, S.F.; MAZZANTI, A.; RAISER, A.G. et al. Reabilitação em cães submetidos à artroplastia do joelho. Ciênc. Rural, v.36, p.1456-1461, 2006.

SURFACE electromyography for the non-invasive assessment of muscles. [s.1.]:Seniam, 2008. Available in: <http: //www.seniam.org/>. Accessed in: 20 Jun 2009.

WEIGEL, J.P.; ARNOLD, G. HICKS, D.A. et al. Biomecânica da reabilitação. In: LEVINE, D.; MILLIS, D.M.L.; MARCELLIN-LITTLE, D.J. Reabilitação e fisioterapia na prática de pequenos animais. 2.ed. São Paulo: Roca. 2008, Cap. 02, p.9-41.

WIJNBERG, I.D.; BACK, W.; JONG, M. et al. The role of electromyography in clinical diagnosis of neuromuscular locomotor problems in the horse. Equine Vet. J., v.36, p.718-722, 2004.

WIJNBERG, I.D.; FRANSSEN, H.; JANSEN, G.H. et al. Quantitative electromyographic examination in myogenic disorders of 6 horses. J. Vet. Intern. Med., v.17. p.185-193. 2003. 